\title{
The Role of Sports Events in Boosting City Brand Equity: The Case of Egypt -
}

\author{
A working paper
}

\author{
Ahmed Adel \\ School of Management, Huazhong University of science and technology, China \\ Faculty of Commerce, Cairo University, Egypt \\ Email: a_adel@mail.hust.edu.cn
}

\author{
Abeer A. Mahrous \\ Professor of Marketing, \\ Cairo University \\ email: abeer.mahrous@,foc.cu.edu.eg \\ Orcid: 0000-0002-6082-4621 \\ Ehab AbouAish \\ Professor of Marketing, \\ Cairo University \\ email: ehab.abouaish@,foc.cu.edu.eg
}

\section{Abstract}

This paper is a working paper that focuses on developing a conceptual framework to investigate the concept of congruence between city identity and sports event image and its impact on both city brand attitude and city brand equity. Very little is known about the impact of hosting mega-events on the attitude toward the hosting destination and needs further analysis (Lee et al., 2014). Furthermore, despite the importance of brand equity (Christodoulides \& de Chernatony 2010), and the fame of events as a tourism marketing tool and helping marketers promote their destination's brand equity, the relationship between events and brand equity has been largely ignored (Zarantonello \& Schmitt, 2013). Finally, the paper suggests the methodology appropriate to empirically examine the suggested conceptual framework.

Keywords: city identity, sports event, city image, city brand, nation brand, brand equity.

\section{Introduction:}

Recently, city branding has gained much reputation among academics and executives (Anholt, 2007) as it became a strategic activity to publicize the City's competitive advantages (Lucarelli \& Berg, 2011). It helps in promoting the City's history, culture, lifestyle, quality of place, prestige, and power (Zhang \& Zhao, 2009). Differentiating cities through branding is important in attracting more investment, more tourists to visit, more citizens to live, and increasing its global ranking (Riza, 2015). 
According to the global city index (2017), which analyzes 128 cities in six world regions, Cairo and Alexandria have been ranked 112 and 116 among the 128 cities. Similarly, Cairo has achieved a low ranking in Global Power City Index (2017) as it came in $43^{\text {rd }}$ place among 44 cities. This low ranking highlights the need to adopt the concept of city branding in Egypt. Consequently, place marketers in Egypt should establish the City as a brand to promote it to its current and potential target audience (Zenker, 2011). Additionally, a city should adopt the right strategies to identify and differentiate itself from its competitors to brand itself successfully (Tsaur et al., 2016).

Nowadays, events are used as a strategy to leverage the nation's brand. As in the current research, event marketing often occurs in sports events (Lee, 2014) because they have extensive media-coverage and can attract numerous sport tourists (Rein \& Shields, 2007). Additionally, they can be represented to improve the host nation's soft power because of its related positive images of fairness, excellence, and universal friendship (Bodet \& Lacassagne, 2012). Therefore, nations worldwide compete to host sports events because countries (and developing countries in particular) desire to exploit such events to build or redefine their image (Walker et al., 2013).

As a result, this study aims to understand the impact of hosting sports events from a marketing communication perspective and a broader branding perspective. It attempts to integrate brand management with events in the context of sports marketing.

Thus, this study concerns investigating the concept of Congruence between city identity and sports event image and its impact on both city brand attitude and city brand equity as very little is known about the impact of hosting mega-events on the attitude toward the hosting destination and needs further analysis (Lee et al., 2014). Furthermore, despite the importance of brand equity (Christodoulides \& de Chernatony 2010), and the fame of events as a tourism marketing tool and helping marketers promote their destination's brand equity, the relationship between events and brand equity has been largely ignored (Zarantonello \& Schmitt, 2013).

\section{Theoretical background:}

This section illustrates the study's theoretical basis, putting the study about brand management and sports marketing. It then conceptualizes the constructs of study; Congruence between host city brand identity and sports event image, host city brand attitude, host city brand equity, and experience with the event.

\subsection{Theory:}

The proposed model is originally developed from the sponsorship literature based on congruence theory and meaning transfer theory (Mahrous, 2013; Mohsen et al. 2018; Mahrous and Kotb, 2014; Marzouk and Mahrous, 2020; Shazly \& Mahrous 2020). Enormous studies in sponsorship literature consider the importance of Congruence or match between the sponsor and the sponsored event (Lee et al., 2016). Drawing on the congruence theory of sponsorship literature, consumers can recall memorized 
information better based on relatedness between the sponsor brand and the sponsored event (Cornwell et al., 2005). Furthermore, the concept of image congruence is characterized as a part of the image transfer process (Grohs \& Reisinger, 2005). According to meaning transfer theory, a high congruence between an event and a brand is required to transfer value from the event to the brand. As a result, when consumers perceive a fit between a sponsor and an event, desired responses, such as favorable attitudes toward the sponsoring brand, will be created (Lee \& Cho, 2009). Accordingly, it is suggested that when consumers perceive Congruence between a host city brand and a sports event, transferring values between the sporting event image and the host city brand will occur, as well as desired reactions will be created towards the host city.

\subsection{City brand identity:}

Much attention has been devoted to brand management literature toward the concept of brand identity (Konecnik \& Go, 2008). Kapferer (2008) quoted the importance of brand identity as "before knowing how we are perceived, we must know who we are." According to this quote, the destination, rather than the consumer, should first start with defining its brand. Aaker (1996) defines brand identity as to how an organization wants to be perceived by its target audience. It represents the vision of a brand; therefore, a brand should have a strong and clear identity because it is the basis for all communication activities (Knape \& Lundell, 2011; Adel \& Mahrous, 2018; Abdelmaaboud, et al. 2020; Mahrous and Kotb, 2014; Adel et al., 2018; Mahrous, 2019; Mahrous, et al., 2010; Mahrous \& Ahmed, 2010, Mahrous \& Abdelmaaboud, 2017, Mahrous, 2016; Mahrous, 2011). Branding destinations is a relatively new phenomenon in its infancy (Caldwell \& Freire, 2004). City branding is regarded as a sub-field of place branding that focuses on cities' marketing and branding for citizens and tourists (Merrilees, Miller \& Herington, 2009). It is considered a more multifaceted and difficult process than the branding of products and services. It includes many factors to consider, such as geography, infrastructure, tourist attractions, local products, natural resources, and residents characteristics (Glinska \& Florek, 2013). A place branding process consists of 1) formulating a vision for the place supported by all stakeholders, 2) relevant actions that are related to infrastructural projects and opportunities for several audiences, and 3) communications of these actions (Kavaratzis \& Hatch, 2013).

\subsection{Sports event image:}

Aaker (1996) defines brand image as the way the target audience sees the brand. It should be backward-looking as opposed to the brand identity that should be forwardlooking. Besides, brand image has been defined as "perceptions about a brand as reflected by the brand associations held in memory" (Keller, 1993, p. 3). Accordingly, Event image can be defined as "the cumulative interpretation of meanings or associations attributed to events by consumers" (Gwinner, 1997, p.147).

Many factors can influence event images such as event type (sports, arts, musical, festival), destination type (urban, rural, coastal, historical), event characteristics (size, venue, history, promotional appearance), individual characteristics (number of 
meanings, the strength of meanings, experience with the event), and information sources (promotion, media reports, opinions of others, personal and direct experience) (Deng et al., 2015; Gwinner, 1997; Hallmann et al., 2010).

In tourism marketing literature, event image has been less investigated than destination image (Deng et al., 2015). Although scholars have focused on the antecedents and consequences of having a positive image of a destination, only a few empirical studies have attempted to comprehend the concept of sports event image and whether the type of destination has an impact on or interaction with event image perceptions (Hallmann et al., 2010).

\subsection{Congruence between city brand identity and sports event image:}

Although the relationship between events and their hosting destinations has received great interest in tourism and sport science, the concept of image congruence between a sporting event and its host destination has been neglected (Hallmann \& Breuer, 2010). It is defined as the perceived affinity between a sporting event and its host destination by the sports tourist. It reflects a part of the image transfer process (Grohs \& Reisinger, 2005). It is derived from the sport sponsorship literature in which the concept of image transfer between an event and its sponsors has been examined widely (Grohs \& Reisinger, 2005; Koo, Quarterman \& Flynn, 2006). Although the research of sports events has intensively examined the concept of congruence fit in the context of sponsorship, there has not been much research investigating consumers' perceived event image. Hence, it can be concluded that the body of literature on sport event image and image congruence is relatively low and mostly referring to the sponsorship (Hallmann \& Breuer, 2010).

\subsection{City brand attitude:}

Attitude is an overall enduring assessment of people, things, or products (Engel, Blackwell \& Miniard, 2006). It is a positive or negative reaction towards them that includes favorable or unfavorable assessment, emotional feelings, and behavioral tendency (Kotler and Keller, 2008). Brand attitude is the consumer's overall assessment of the brand ( $\mathrm{Wu} \&$ Wang, 2011). There are three components of attitudes: 1) cognitive component (knowledge formed after information obtained or direct experience), 2) affective component (feelings and emotions towards a brand), and 3) conative component (behavioral tendency towards a brand) (Assael, 2004).

Recently, brand attitude is used to evaluate the effectiveness of event marketing. In an event marketing context, a brand attitude refers to consumers' attitudes toward the brand related to a given event. Although it is relatively stable, it can change over time. One of the most important objectives of marketing communications today is supporting brand attitude (if it is already positive) or altering it (if it is negative) (De Pelsmacker, Geuens \& Van den Bergh, 2007). Over the past years, it has been used to assess marketing communications' effectiveness, especially advertising (Gupta 2003). Zarantonello \& Schmitt (2013) argued that advertising messages should affect consumers' attitudes toward the advertisement's brand. 


\subsection{City brand equity:}

The concept of brand equity was developed in the late 1980s and has been widely used by academics and practitioners since (Veloutsou, Christodoulides, \& de Chernatony, 2013). Although there is no agreement on a universally accepted definition of it, there is some consensus that brand equity expresses the value-added that is exclusively attributed to the brand in the customer's mind (Christodoulides \& de Chernatony, 2010). Aaker (1991, p. 15) defined brand equity as "a set of assets and liabilities linked to a brand, its name, and symbol, that adds to or subtracts from the value provided by a product or service to a firm and that firm's customers." Based on the product brand equity definition by Aaker (1991), city brand equity can be defined as "real and perceived assets and liabilities that are associated with a place and distinguish it from others" (Jacobsen, 2012).

There are two major perspectives measuring brand equity; the firm's perspective that is linked to the financial value of the brand, and the consumer-based brand equity (CBBE) that is related to the perceptions and attitudes of consumers toward a brand (Veloutsou, Christodoulides, \& de Chernatony, 2013). This research adopts the second perspective because it is more relevant in the context of places as the critical The goal of places is not a financial success; however, their residents' well-being and satisfaction (Fatema, Azad, \& Masum, 2013; Florek, 2012).

\section{Research problem:}

Mårtensson (2009) argues that a destination should build a strong and clear identity because it is the basis for all communication activities. Furthermore, it is recommended to investigate destination identity's impact on event image and interaction (Hallmann et al., 2010). This interaction can be presented through the concept of image congruence between a sporting event and its host destination, which has been neglected in tourism and event marketing literature (Hallmann \& Breuer, 2010). Additionally, it is argued that image unity may lead to a favorable attitude towards the brand. There is a need to examine the effect of hosting mega-events on the hosting destination's attitude (Lee et al., 2014; Lee \& Cho, 2009). Moreover, it is recommended to study brand equity from a sporting perspective (Ross, 2006). Based on those mentioned above, the research problem of this study is to "explore how to constitute image congruence through fitting host city brand identity with sports event marketing communication and examining the impact of congruence between host city brand identity and sports event image on both host city brand attitude and host city brand equity as well as investigating the moderating role of experience with the event."

\section{Hypotheses development and conceptual research framework: 4.1 Congruence between city brand identity and sports event image \& City brand equity:}

Brand image is a crucial factor that affects brand equity (Lee, Lee \& Wu, 2011, Ragb et al., 2019, Ragb et al. 2020). Event marketing is nowadays conceptualized as a 
means for building brand equity (Keller, 2009). Only a few studies have investigated brand equity from a sporting perspective (Ross, 2006). Previous studies have investigated the impacts of event marketing on specific dimensions rather than overall brand equity (Zarantonello \& Schmitt, 2013); however, only a few studies have investigated the impacts of event marketing on overall brand equity (Groza, Cobbs \& Schaefers, 2012; Zarantonello \& Schmitt, 2013). Therefore, this study will focus on exploring overall brand equity rather than its single dimensions.

H1. Congruence between city brand identity and sports event image has a positive impact on city brand equity.

\subsection{Congruence between city brand identity and sports event image \& city brand attitude:}

An understanding of sports event image can help improve a destination image to create a desirable attitude toward it that, in turn, attracts more visitors (Chalip \& Green, 2001). The consumer also forms an overall brand attitude based on its image (Wu \& Wang, 2011). Moreover, Kressmann et al. (2006) argued that high selfcongruity between the consumer and the brand is likely to form a favorable attitude. Similarly, Liu, Mizerski, and Soh (2012) found that image congruity is a stronger predictor of brand attitude. Therefore,

H2. Congruence between city brand identity and sports event image has a positive impact on city brand attitude.

\subsection{City brand attitude and city brand equity:}

Faircloth, Capella, and Alford (2001) claimed that brand attitude represents one of the critical drivers of brand equity. Similarly, Park et al. (2010) argued that it acts as a source of brand equity. Additionally, Zarantonello \& Schmitt (2013) concluded that brand attitudes mediate between events and brand equity. Consequently,

H3. City brand attitude has a positive impact on city brand equity.

H4. City brand attitude mediates the relationship between Congruence between city identity and sports event image and city brand equity.

\subsection{The moderating role of Past Experience with Event:}

Gwinner (1997) suggested that the sports event image might be affected by past encounters with the occasion. Similarly, experience with the sports event will positively influence the event image (Kaplanidou \& Vogt, 2007). Additionally, it is argued that experience plays an important role in attitude-behavior theories (Eagly \& Chaiken, 1993). Thus,

H5. The impact of Congruence between city identity and sports event image on city brand equity will differ significantly based on experience with sports events (i.e., positive and negative). 


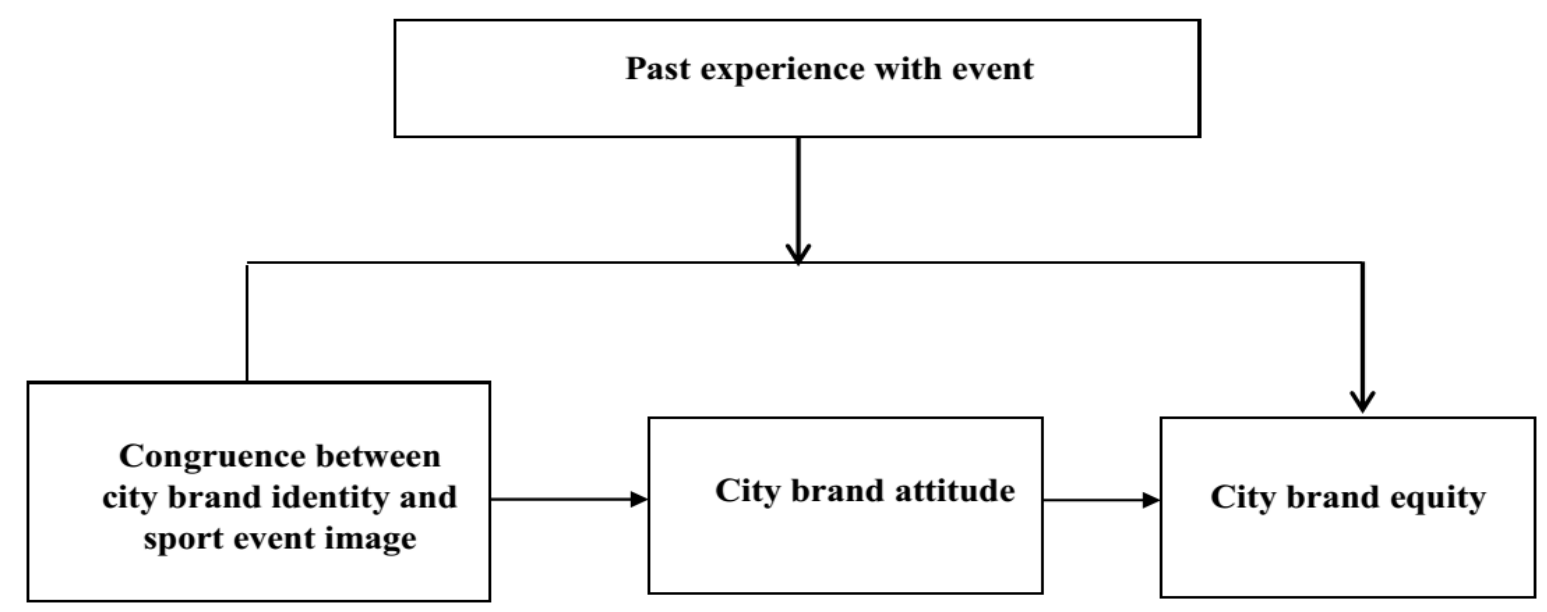

Figure (1) Research Conceptual Framework

\section{Research methodology:}

The mixed-methods approach will be followed (Shazly, \& Mahrous, 2020). First, qualitative exploratory research will be employed. In-depth interviews will be conducted with sports fans and sports and tourism marketing experts to gain further insight into their view of the subject area and identify how to form image congruence between the host city and sporting event. In this stage, open-ended questions will be asked to gain further insights about their perception of dimensions of city brand identity, how to associate host city brand identity with sports event marketing communications, to what extent this association could affect image congruence, the expected impact of image congruence on both host city brand attitude, and host city brand equity.

Second, the research follows the quantitative approach to test the specific hypotheses and investigate the previously outlined constructs' relationships.

An experimental design using controlled scenarios will be conducted. In particular, study 1 will be conducted to examine the direct impact of image congruence on city brand attitude and city brand equity and the mediated impact of city brand attitude on city brand equity. In study 2 , it is proposed to replicate the main effects of study 1 and test the impact of moderating the role of experience with an event.

\section{Study1:}

A between subjects, $2 \times 2 \times 2$ experimental factorial design will be designed, with two levels of the character of the host city (coastal - heritage), two levels of culture (iconic architecture - non-iconic architecture), and two levels of sports event marketing communication (high fit with the character of the host city - poor fit with the character of host city). The reason behind employing these two dimensions of host city brand identity (character and culture) is the call for investigating the impact of the type of destination in sport event context as recommended by Hallmann et al. (2010) Khattab and Mahrous (2016) and Konecnik and Go (2008). Furthermore, there is a 
new trend to link between mega-events and iconic architecture (that is a part of the host city culture) as strategies for city brand (Riza, 2015). Additionally, they are the most commonly used in a sports event context. According to Caldwell \& Freire (2004), tourists prefer to visit cities because of the place's attractions (museums, beaches, mountains, and sky).

A professional website developer will develop a website from scratch to modify it to fit all the possible experimental scenarios. Each scenario will be assigned randomly to each respondent. Respondents will be asked to visit the website to evaluate the image congruence between host city brand identity and sports event without mentioning the experiment's real purpose to ensure that they behave normally. The website will include three main sections representing information, photos, and videos about host city character and culture and sports event marketing communication (logo, slogan, colors, online advertising, and publicity).

\section{Study 2:}

A between subjects, $2 \times 2 \times 2 \times 2$ experimental factorial design will be designed, with two levels of the character of the host city (coastal - heritage), two levels of culture (iconic architecture - non-iconic architecture), two levels of sports event marketing communication (high fit with the character of the host city - poor fit with the character of host city) and two levels of experience with sports event (positivenegative).

Procedures of study 2 will be similar to study 1 ; however, what will be added is that each subject will also be exposed to a positive or a negative experience with the sporting event.

Then, a self-administered online questionnaire will be used. A message will appear after the experiment to direct the participants to the online survey website (Qulatrics.com). The questionnaire will be translated into Arabic following the back translation procedures proposed by Brislin (1986). This self-administrated structured questionnaire will include questions about the Congruence between host city brand identity and sports event image, host city brand attitude, and host city brand equity.

\section{Expected contribution:}

\subsection{Theoretical contribution:}

Theoretically, this research attempts to fill the gaps in the tourism marketing and sports events literature by conceptualizing the constructs mentioned above and proposing a model that depicts the relationships between them. Also, it contributes to a better understanding of how sports events work from a broader branding perspective and how they contribute to the improvement of brand equity. Furthermore, this research will be applied in a new Egyptian context, in which very little published research was undertaken to address these constructs in a sports marketing context.

\subsection{Practical contribution:}


For sports events and tourism marketers, this research is expected to draw conclusions that help them better make their marketing decisions when hosting sports events; in particular, Egypt has won the honor of organizing the 2019 African Cup of Nations and the 2021 World Men's Handball Championship. It may help marketers constitute image congruence between the host city and sports event to communicate and promote the host city. Additionally, it sheds some light on the importance of the image transfer process that can reinforce the positive attitudes or alter the host city's negative ones. Moreover, it demonstrates how sports events should be regarded as marketing tools contributing to building brand equity. 


\section{References:}

Aaker, D. A. (1996). Building Strong Brands. New York: The Free Press.

Aaker, D.A. (1991). Managing brand equity: capitalizing on the value of a brand name, NY: The free press, Macmillan.

Abdelmaaboud, A. K., Peña, A. I. P., \& Mahrous, A. A. (2020). The influence of student-university identification on student's advocacy intentions: the role of student satisfaction and student trust. Journal of Marketing for Higher Education, 1-23.

Adel, H. M., Zeinhom, G. A., \& Mahrous, A. A. (2018). Effective management of an internationalization strategy: A case study on Egyptian-British universities' partnerships. International Journal of Technology Management \& Sustainable Development, 17(2), 183-202

\&Adel, Heba M.

Mahrous, Abeer A. (2018, September 4-6). Sustainability communication and evaluation: A practice-based case study on British-Egyptian universities value-chain, Paper presented at British Academy of Management Conference: Driving Productivity in Uncertain and Challenging Times, Bristol Business School: University of The West of England.

Anholt, S. (2007). Competitive Identity. The New Brand Management for Nations, Cities and Regions, Palgrave Macmillan, New York.

Assael, H. (2004), Consumer Behavior: A Strategic Approach, Hunghton Mifflin Company, Boston, MA.

Bodet, G., \& Lacassagne, M. F. (2012). International place branding through sporting events: a British perspective of the 2008 Beijing Olympics. European Sport Management Quarterly, 12(4), 357-374.

Brislin, R. W. (1986). Research instruments. Field methods in cross-cultural research, 8, 137-164.

Brown, G., Smith, A., \& Assaker, G. (2016). Revisiting the host city: An empirical examination of sport involvement, place attachment, event satisfaction and spectator intentions at the London Olympics. Tourism management, 55, 160-172.

Caldwell, N., \& Freire, J. R. (2004). The differences between branding a country, a region and a city: Applying the Brand Box Model. Journal of brand management, 12(1), 50-61. 
Chalip, L., \& Green, B. C. (2001, January). Event marketing and destination image. In American Marketing Association. Conference Proceedings (Vol. 12, p. 346). American Marketing Association.

Christodoulides, G., \& De Chernatony, L. (2010). Consumer-based brand equity conceptualization and measurement: A literature review. International Journal of Research in Marketing, 52(1), 43-66.

Cornwell, T. B., Weeks, C. S., \& Roy, D. P. (2005). Sponsorship-linked marketing: Opening the black box. Journal of advertising, 34(2), 21-42.

de Pelsmacker, P., Geuens, M. \& Van den Bergh, J. (2007) Marketing communications: a European perspective. London: Pearson Education.

Deng, C. Q., Li, M., \& Shen, H. (2015). Developing a measurement scale for event image. Journal of Hospitality \& Tourism Research, 39(2), 245-270.

Eagly, A.H., \& Chaiken, S. (1993). The psychology of attitudes. Orlando: Harcourt Brace College Publishers.

Engel, J.E., Blackwell, R.D. and Miniard, P.W. (2006), Consumer Behavior, 10th ed., Harcourt Brace Jovanovich, New York, NY.

Faircloth, J. B., Capella, L. M., \& Alford, B. L. (2001). The effect of brand attitude and brand image on brand equity. Journal of Marketing Theory and Practice, 9(3), 61-75.

Fatema, M., Azad, M. A. K., \& Masum, A. K. M. (2015). Impact of Brand Image and Brand Loyalty in Measuring Brand Equity of Islami Bank Bangladesh Ltd. Asian Business Review, 2(1), 42-46.

Florek, M. (2012). Measurement of city brand equity. Actual Problems of Economics, (133), 130-139.

Glinska, E., \& Florek, M. (2013). Stakeholders' involvement in designing brand identity of towns-Podlaskie region case study. Actual Problems of Economics, (10), 274-282

Green, B. C., Costa, C., \& Fitzgerald, M. (2003). Marketing the host city: Analyzing exposure generated by a sport event. International Journal of Sports Marketing and Sponsorship, 4(4), 48-66.

Grohs, R., \& Reisinger, H. (2005). Image transfer in sports sponsorships: An assessment of moderating effects. International Journal of Sports Marketing \& Sponsorship, 7(1), 42-48. 
Groza, M., Cobbs, J., \& Schaefers, T. (2012) Managing a sponsored brand: the importance of sponsorship portfolio congruence. International Journal of Advertising, 31(1), 63-84.

Gupta, S. (2003) Event marketing: issues and challenges. IIMB Management Review, 15(2), pp. 87- 96.

Gwinner, K. (1997). A model of image creation and image transfer in event sponsorship. International marketing review, 14(3), 145-158.

Hallmann, K., \& Breuer, C. (2010). Image fit between sport events and their hosting destinations from an active sport tourist perspective and its impact on future behaviour. Journal of Sport \& Tourism, 15(3), 215-237.

Hallmann, K., Kaplanidou, K., \& Breuer, C. (2010). Event image perceptions among active and passive sports tourists at marathon races. International Journal of Sports Marketing and Sponsorship, 12(1), 32-47.

Jacobsen, B. P. (2012). Place brand equity: a model for establishing the effectiveness of place brands. Journal of Place Management and Development, 5(3), 253-271.

Kapferer, J. N. (2008). The New Strategic Brand Management: Creating and Sustaining Brand Equity.

Kaplanidou, K., \& Vogt, C. (2007). Path analysis of sport event image influence on spectator's intentions to revisit the hosting destination. In North American Society for Sport Management Conference, Florida, FT (pp. 379-380).

Kavaratzis, M., \& Hatch, M. J. (2013). The dynamics of place brands: An identitybased approach to place branding theory. Marketing theory, 13(1), 69-86.

Keller, K. L. (1993). Conceptualizing, measuring, and managing customer-based brand equity. Journal of Marketing, 1-22.

Keller, K. L. (2009). Building strong brands in a modern marketing communications environment. Journal of marketing communications, 15(2-3), 139-155.

Khattab, L., \& Mahrous, A. A. (2016). Revisiting online banner advertising recall: An experimental study of the factors affecting banner recall in an Arab context. Journal of Arab \& Muslim Media Research, 9(2), 237-249.

Knape, E., \& Lundell, H. (2011). The Brand Identity and Brand Image Of Gothenburg-A Case Study Of Way Out West.

Konecnik, M., \& Go, F. (2008). Tourism destination brand identity: The case of Slovenia. Journal of Brand Management, 15(3), 177-189. 
Koo, G.-Y., Quarterman, J., \& Flynn, L. (2006). Effect of perceived sport event fans sponsor image fit on consumers' cognition, affect, and behavioural intentions. Sport Marketing Quarterly, 15(2), 80-90.

Kotler, P. and Keller, K.L. (2008), Marketing Management, 13th ed., Prentice-Hall, Upper Saddle River, NJ.

Kressmann, F., Sirgy, M. J., Herrmann, A., Huber, F., Huber, S., \& Lee, D. J. (2006). Direct and indirect effects of self-image congruence on brand loyalty. Journal of Business Research, 59(9), 955-964.

Lee, C. J. (2014). Effects of sport mega-events on city brand awareness and image: using the 2009 world games in Kaohsiung as an example. Quality \& Quantity, 48(3), 1243-1256.

Lee, H. M., Lee, C. C., \& Wu, C. C. (2011). Brand image strategy affects brand equity after M\&A. European journal of marketing, 45(7/8), 1091-1111.

Lee, H. S., \& Cho, C. H. (2009). The matching effect of brand and sporting event personality: Sponsorship implications. Journal of Sport Management, 23(1), 41-64.

Lee, T. S., Huh, C. L., Yeh, H. M., \& Tsaur, W. G. (2016). Effectiveness of a communication model in city branding using events: The case of the Taiwan Lantern festival. International Journal of Event and Festival Management, 7(2), 137-148.

Lee, Y. K., Kim, S., Lee, C. K., \& Kim, S. H. (2014). The impact of a mega event on visitors' attitude toward hosting destination: Using trust transfer theory. Journal of Travel \& Tourism Marketing, 31(4), 507-521.

Liu, F., Li, J., Mizerski, D., \& Soh, H. (2012). Self-congruity, brand attitude, and brand loyalty: a study on luxury brands. European Journal of Marketing, 46(7/8), 922-937.

Lucarelli, A., \& Berg, P. (2011). City branding: a state-of-the-art review of the research domain. Journal of place management and development, 4(1), 9-27.

Mahrous, A. A. (2011). Antecedents of privacy concerns and their online actual purchase consequences: a cross-country comparison. International Journal of Electronic Marketing and Retailing, 4(4), 248-269

Mahrous, A. A. (2013). Social Media Marketing: Prospects for Marketing Theory and Practice on the Social Web. In E-Marketing in Developed and Developing Countries: Emerging Practices (pp. 56-68). IGI Global.

Mahrous, A. A. (2016). Implications of the use of social media for pre-purchase information searches for automobiles. International Journal of Technology Marketing, 11(3), 254-275. 
Mahrous, A. A. (2019). Female entrepreneurship in Egypt: new theoretical and public policy implications. Маркетинг і менеджмент інновацій, (1), 151-160.

Mahrous, A. A., \& Abdelmaaboud, A. K. (2017). Antecedents of participation in online brand communities and their purchasing behavior consequences. Service Business, 11(2), 229-251.

Mahrous, A. A., \& Ahmed, A. A. (2010). A cross-cultural investigation of students' perceptions of the effectiveness of pedagogical tools: The Middle East, the United Kingdom, and the United States. Journal of Studies in International Education, 14(3), 289-306.

Mahrous, A. A., \& Hassan, S. S. (2017). Achieving superior customer experience: An investigation of multichannel choices in the travel and tourism industry of an emerging market. Journal of Travel Research, 56(8), 1049-1064.

Mahrous, A. A., \& Kotb, A. (2014, June). Antecedents of virtual communities participation and their purchasing behavior consequence. In Proceedings of the 4th Conference of the International Network of Business \& Management Journals (INBAM), Management Decision, Barcelona, 25-27 June.

Mahrous, A., Genedy, M. A., \& Kalliny, M. (2020). The impact of characteristics of intra-organizational environment on entrepreneurial marketing intensity and performance in Egypt. Journal of Entrepreneurship in Emerging Economies

Mahrous, A., Kortam, W., \& Anis, A. (2010). The role of students' expectations and evaluations in the learning process and market orientation of business schools in Egypt. In British Academy of Marketing Conference, Coventry Business School, Coventry, $U K$ (pp. 1-7).

Marzouk, O. A., \& Mahrous, A. A. (2020). Sustainable Consumption Behavior of Energy and Water-Efficient Products in a Resource-Constrained Environment. Journal of Global Marketing, 1-19

Merrilees, B., Miller, D., \& Herington, C. (2009). Antecedents of residents' city brand attitudes. Journal of Business Research, 62(3), 362-367.

Mohsen, Y., Hussein, H. M., \& Mahrous, A. A. (2018). Perceived service value, customer engagement and brand loyalty in health care centres in Egypt.

Park, C., MacInnis, D. J., Priester, J., Eisingerich, A. B., \& Iacobucci, D. (2010). Brand attachment and brand attitude strength: Conceptual and empirical differentiation of two critical brand equity drivers. Journal of marketing, 74(6), 1-17.

Ragab, H., Mahrous, A. A., \& Ghoneim, A. (2019). Egypt's perceived destination image and its impact on tourist's future behavioural intentions. International Journal of Tourism Cities. 
Ragb, H., Mahrous, A. A., \& Ghoneim, A. (2020). A proposed measurement scale for mixed-images destinations and its interrelationships with destination loyalty and travel experience. Tourism Management Perspectives, 35, 100677.

Rein, I., \& Shields, B. (2007). Place branding sports: Strategies for differentiating emerging, transitional, negatively viewed and newly industrialised nations. Place Branding and Public Diplomacy, 3(1), 73-85.

Riza, M. (2015). Culture and City branding: Mega-events and iconic buildings as fragile means to brand the City. Open Journal of Social Sciences, 3(07), 269.

Ross, S. D. (2006). A conceptual framework for understanding spectator-based brand equity. Journal of sport Management, 20(1), 22-38.

Shazly, R. E., \& Mahrous, A. A.(2020) Capture the hearts to win the minds: cause-related marketing in Egypt. International Review on Public and Nonprofit Marketing, 1-22.

Tsaur, S. H., Yen, C. H., \& Yan, Y. T. (2016). Destination brand identity: scale development and validation. Asia Pacific Journal of Tourism Research, 21(12), 13101323.

Veloutsou, C., Christodoulides, G., \& de Chernatony, L. (2013). A taxonomy of measures for consumer-based brand equity: drawing on the views of managers in Europe. Journal of Product \& Brand Management, 22(3), 238-248.

Walker, M., Kaplanidou, K., Gibson, H., Thapa, B., Geldenhuys, S., \& Coetzee, W. (2013). "Win in Africa, With Africa": Social responsibility, event image, and destination benefits. The case of the 2010 FIFA World Cup in South Africa. Tourism management, 34, 80-90.

Wu, P. C., \& Wang, Y. C. (2011). The influences of electronic word-of-mouth message appeal and message source credibility on brand attitude. Asia Pacific Journal of Marketing and Logistics, 23(4), 448-472.

Zarantonello, L., \& Schmitt, B. H. (2013). The impact of event marketing on brand equity: The mediating roles of brand experience and brand attitude. International Journal of Advertising, 32(2), 255-280.

Zenker, S. (2011). How to catch a city? The concept and measurement of place brands. Journal of Place Management and Development, 4(1), 40-52.

Zhang, L., \& Zhao, S. X. (2009). City branding and the Olympic effect: A case study of Beijing. Cities, 26(5), 245-254. 